\title{
Community Involvement in Urban Water Management: The N Park Resort Condominium Rainfall Harvesting and Water Saving Project in Penang, Malaysia
}

\author{
Ngai Weng Chan ${ }^{1}$, Jabil Mapjabil2 ${ }^{2}$ Narimah Samat ${ }^{1}$, Mou Leong Tan¹, \\ Aminuddin Ab Ghani ${ }^{3}$, and Fei Zhang ${ }^{4}$
}

\begin{abstract}
${ }^{1}$ School of Humanities, Universiti Sains Malaysia, Penang, Malaysia, ${ }^{2}$ Borneo Institute for Indigenous Studies (BorlIS), Universiti Malaysia Sabah, Sabah, Malaysia, ${ }^{3}$ River Engineering \& Urban Drainage Research Centre, Universiti Sains Malaysia, Penang, Malaysia, ${ }^{4}$ College of Resources and Environmental Science, Xinjiang University, Urumqi 830046, China
\end{abstract}

Corresponding Author: Jabil Mapjabil (email: jabil@ums.edu.my)

\begin{abstract}
Community engagement and involvement is vital for the success of urban water management. However, poor public engagement, cheap water tariffs, apathetic attitude and lack of public interest are identified as the main reasons for high water wastage in Penang State, Malaysia. The $\mathrm{N}$ Park Resort Condominium rainfall harvesting and water saving project in Penang, Malaysia is a prime example of successful urban water management involving government, private sector, non-governmental organisations (NGOs) and local communities. The N-Park condominium consisting of 965 units is the first condominium in the country to initiate a community watersaving project. Started in August 2009 and completed in December 2010, the project is jointly implemented by the Drainage and Irrigation Department (DID) Malaysia (Government), Water Watch Penang (WWP) (NGO), N-Park Management Corporation (NPMC)(Community) and the Penang Water Supply Corporation (PWSC). The methodology involved installation of a rainwater harvesting system, installation of water-saving devices and a water-saving campaign. Results of the project showed that the rainwater harvesting system was most successful as the rainwater harvested was used for gardening, washing common areas and toilets, flushing toilets, and washing vehicles. The installation of water-saving devices was also successful as it resulted in substantial water savings. Results showed reduced total water usage from 8 to 25 $\%$ between September 2009 to March 2010. The greatest reduction by $50 \%$ was between May and July 2011 , followed by $47.5 \%$ in January 2011. During the time of the project, the amount of water saved was equivalent to RM1,397 in monetary savings per month. Over a year, this is translated to a savings of $16,818 \mathrm{~m}^{3}$ of water or the equivalent of RM 16,782. More recently, between February 2020 and April 2021, the average water saved was $5852 \mathrm{~m}^{3}$ per month or averaging $48.77 \%$ per month, equivalent to about RM34,255. Results also showed enhanced water awareness and better relationships between neighbours. Overall, this project proved that collaboration between government-private sector-NGOs is workable, and the project can be replicated nation-wide in apartments, hotels, factories, universities, and schools.
\end{abstract}

Keywords: water demand management; water saving devices; rainfall harvesting; water conservation

1 RM is the Malaysian currency unit. RM1 approximates US\$0.24 on 16 September 2017. 


\section{Introduction}

Penang experiences a wet equatorial climate with copious rainfall whereby all months receive rainfall. According to Köppen and Geiger (Geiger, 1954), Penang's climate is classified as Af, referring to Tropical rainforest climate. Hence, the state is considered a "wet" state in terms of rainfall. Based on an average annual rainfall of between $2400 \mathrm{~mm}$ to $2800 \mathrm{~mm}$, it should be considered "rich" in terms of annual renewable surface water. However, the main problem is that the state is considered "water poor" whereby the state's area is small and most of its forests and water catchments have been destroyed and replaced by urban, industrial and agricultural land uses. Penang State has a total land area of 103,945 ha of which only 7758 ha is forest (7.46\%). Of this, water catchments make up only 5956 ha $(5.73 \%)$ (Noresah et al., 2010). Although all the water catchments are now gazetted as water catchments, the area of water catchments is very small and not adequate to generate enough water resources for the people, industry, agriculture and other needs. On top of that, more seriously, more than $80 \%$ of Penang's water supply is sourced from the Muda River which originates from another state Kedah $(\mathrm{Hj}$ Keizrul Abdullah, 2002). Consequently, despite being endowed with abundant rainfall, Penang is considered by many as being a "water-stressed" state which is often plagued by serious water problems that have threatened its current and future water security (Chan, 2002; Quah, 2011; Maidinsa, 2017).

Although Malaysia, as a country, has per capita renewable water of more than 17,000 $\mathrm{m}^{3}$ per annum, which is more than ten times the international water stress line of 1,700 $\mathrm{m}^{3}$ per capita per annum, Penang State by comparison is poor as it only has $600 \mathrm{~m}^{3}$ per capital renewable water annum (Chan, 2017). In addition, water pollution, wastage, low water tariffs and public apathy results in a lot of water problems that are largely caused by human (Chan, 2009; Chan, 2012a). Penang is one of the most developed states in Malaysia. Even during colonial times, Penang was well developed with the premier port in the country. Consequently, land use change has been rapid with water resources depleted by destruction of water catchments (due to forest and land clearance for agriculture, highway construction, dam construction, industries, residential areas etc). Combined with river pollution, water wastage, high nonrevenue water, low tariffs, lack of incentives for water conservation, and public apathy, Penang's water security is threatened (Chan, 2004; Chan, 2017a). The state also lacks strong institutional arrangements due to the traditional government agencies set-up that promotes sectoral water management, and the absence of a central water agency that can promote inter-agency cooperation. In addition, poor institutional arrangements are manifested in inter-state disputes, statelocal government disagreements, sectoral competition of water resources, and other issues. Hence, human mismanagement is the fundamental reason for creating most of Penang's water problems. Yet, despite the fact that most of the water problems are human-caused, Penang still relies heavily on the Structural Paradigm to solve its water problems, i.e. via employing top-down engineering and technical solutions such as construction of dams, water treatment plants, inter-state water transfers, sourcing for alternative water sources, etc. Such an approach does not tackle the root/ fundamental causes that threaten the state's water security. It addresses only the technical side of the problems without involving the human-side. This is not a sustainable method to ensure sustainable future water resources. To successfully address water problems and ensure water security, it is imperative that Penang tackles both the technical as well as the human contexts that threaten its water security (Chan, 2010a; Chan, 2012b). 
Penang's water woes which are manifested in terms of frequent occurrence of water crises/droughts, floods, water pollution, poor water quality, public apathy, and highwater wastage. These reasons are not due to nature or climate change, but largely due to human-causes such as destruction of water catchments, land-use change, urbanization, littering and water pollution, water wastage, low tariffs, public apathy, lack of political will in restructuring tariffs, and inter-state water disputes with Kedah State (Chan, 2017b). Combined with other factors, including climate change, the water equation in Penang has radically changed from one of relative abundance to one of relative scarcity. Factors such as population explosion (including in-migration from neighbouring countries), rapid urbanisation, agricultural expansion, industrialisation, tourism, and other developments have imposed excessive demands and pressures on Penang's water resources. At the same time, water availability is depleted by pollution. All these seriously threaten Penang's water security. The authorities have preferred to tackle all these water problems with the Water Supply Management (WSM) approach which is based solely on technology without addressing the human issues that are really the root causes of these water problems. Water Demand Management (WDM) has been shown to be highly effective in countries such as Singapore, Denmark, and Japan. Penang and Malaysia can, and must adopt WDM. WDM is the control of one's water demand and it is imperative that state and country both embrace this new paradigm as one of its priority strategies to ensure its water security (Tortalajada, 2006).

Traditionally, government agencies, private sector and NGOs worked separately in the area of water management. In the project described in this paper, however, the importance of involving all relevant stakeholders is emphasised. Hence, in this project, besides the residents, the N-Park
Management Corporation and its staff were also actively involved. So too was the water company PBAPP Sdn Bhd, as well as the Government Department named Drainage and irrigation Department (DID) Penang State Branch. Water Watch Penang, the lead NGO, was also instrumental in moving the project (www.waterwatchpenang.org accessed 17 September 2017).

\section{Research Methods}

This water saving project is an initiative funded by the Malaysian Government (via Economic Planning Unit), managed by the Department of Irrigation and Drainage (DID) Malaysia, and jointly carried out by DID, Water Watch Penang (WWP), N-Park Management Corporation (NPMC), and Penang Water Supply Corporation (PWSC). This pilot project, first of its kind in Malaysia, is based on a mixed methodology of changing both the hardware (i.e. installing a rainfall harvesting system and changing the piping system, as well as changing traditional water wasting fittings to water saving fittings) (Figure 1) and changing the software (i.e. changing human behaviour from water-wasting to water-saving via installation of water saving gadgets in individual households and increasing awareness and sensitizing the inhabitants) (Phang et al., 2013). The project consists of 3 components: (i) Installation of a rainfall harvesting system; (ii) Installation of water savings fittings in the common toilets; and (iii) Water-Saving Campaign that includes installation of minor water saving fittings in 100 selected residential units (Table 1), coupled with increasing awareness and education amongst residents in the entire condominium. Water saving fittings are installed in the kitchen and toilets of each participating households as the main objective of this project is to reduce the water consumption of the condominium. The main objective of this pilot project is to reduce piped water usage by $10 \%$ annually. Prior to 
the project initiation, the researchers did an assessment of the participants awareness about their general awareness on water and environmental issues and it was found that residents were of low awareness or could not care less since water was cheap and available freely without problems. Data analysis involves monitoring the amount of rainwater harvested in the 6 rainfall harvesting tanks (each holding a maximum of 10,000 litres), whereby the meter readings are read at the end of each month. The amount of rainwater used is also recorded every month. Similarly, the amount of piped water consumption of the common areas of the condominium and the water consumption of the 100 Participating units were also monitored at the end of each month, before and after the rainfall harvesting system, water saving devices and water saving campaign were launched. Monthly meetings were also held for all the condominium inhabitants to discuss about the problems and solutions of the project. Table 1 shows a total of 100 residents (100 apartment units out of the 965 units) taking part in the individual household water saving exercise.

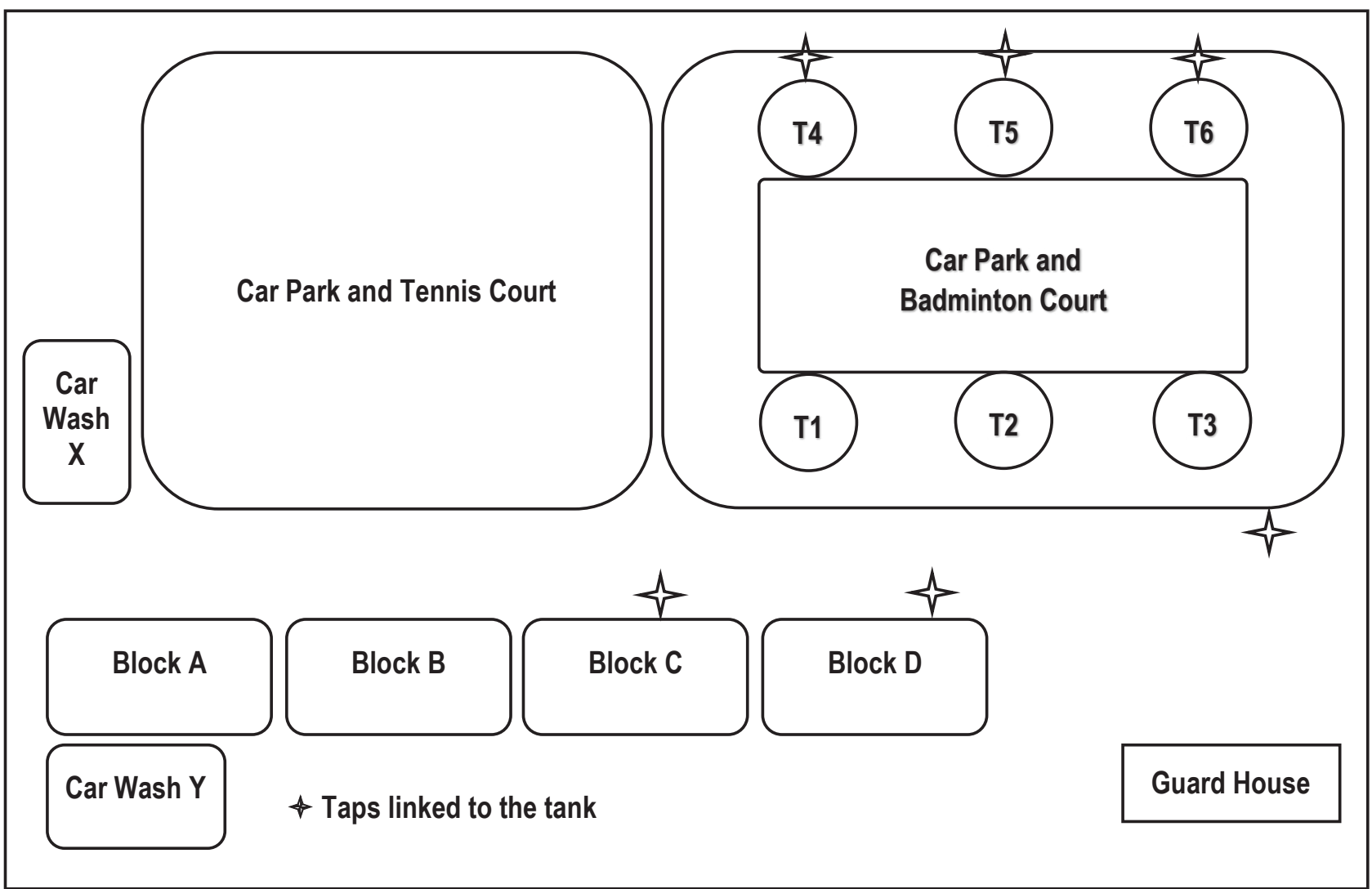

Source: Final Report of N Park Negalitres Project 2010 Submitted to Drainage and Irrigation Department Penang

Note: T1-T6 are the tanks

Figure 1. Layout for Installation of Rainwater Harvesting Tanks 
Community Involvement in Urban Water Management: The N Park Resort Condominium Rainfall Harvesting and Water Saving Project in Penang, Malaysia

Table 1. Total Number of Residents Taking Part in the Individual Household Water Saving Exercise

\begin{tabular}{lrr}
\hline Ethnicity & Frequency & Percentage \\
\hline Malay & 5 & $5 \%$ \\
Chinese & 75 & $75 \%$ \\
Indian & 8 & $8 \%$ \\
Foreigners* & 12 & $12 \%$ \\
Total & 100 & $100 \%$ \\
\hline
\end{tabular}

${ }^{*}$ The number of foreigners staying in N Park Condominium is quite high as the condominium is located very close to Universiti Sains Malaysia.

\section{Implementation}

The project was first mooted in early 2008 by civil society in consultation with DID and private consultants. A buy-in meeting was subsequently held in end 2008 between DID, private consultants, WWP, PWSC, the condominium management and the residents (Chan, 2010b). During this meeting, the project was proposed to the residents and the condominium management whereby the project was accepted. Following this, the project finally kicked off with the official launch on $21^{\text {st }}$ August 2009. On $31^{\text {st }}$ October 2009, the Rainwater Harvesting Project was launched after months of installation. This system consists of 6 sets of rainwater harvesting tanks of 10,000 litres each. The tanks were installed after several months of preparatory survey repairs to existing roofs and gutters, connecting o tanks, and other plumbing works. The official launching was officiated by the (then) Director of DID Penang, Tuan Haji Hanapi bin Mohamad Noor together with Professor Dr Chan Ngai Weng representing WWP and NPMC. The rainwater harvesting project is the first in the nation for condominium units.

Following the launch, the water conservation project for household units kicked-off. Initially about 60 residents from the Block $A, B, C$ and $D$ of N-Park condominium agreed to participate in this project. The participants were visited by two water auditors every Wednesday, Friday and
Saturday (night-time during the weekdays and daytime during the weekends) every month. The auditors also discussed with residents regarding the household water survey questionnaire. The questions included: Water usage pattern (total liter per day per capita); Water saving techniques practiced at home; Willingness to pay for the water saving equipment; Perception on the current water rates in Penang; Willingness to pay for increment of water rates in Penang; and other water related issues. Once a month, the participants had a meeting and were briefed about the project, led by a trainer. Volunteers were trained and their performance assessed before certifying them fit to run the activities. The researchers observe and assess all the volunteers and then picked out the enthusiastic and committed ones to facilitate the training sessions. The sessions discussed about the rainwater harvesting project, the water efficient fittings in the common area toilets, as well as the effectiveness of the household water saving fittings and the problems faced. Participants were also constantly being educated about water conservation in Penang in order to increase their awareness and to instill a sense of caring for water towards creating a water saving community in N-Park, which is part of the main objective of this water conservation project. The trainers/teachers were selected from a pool of volunteers. During the sessions, educating the participants involved first giving a talk/lecture to give them a general idea 
and background of the topic. The speaker selected is that of a good speaker who is able to keep the participants interested. Lots of stories, pictures, video clips and music are incorporated to make the talk interesting. This was followed open discussions and $Q$ \& A session. The researchers also use video documentaries, drama, exhibition, and water painting competition to increase awareness and education on water. During the training sessions, various topics discussed are as follows: (i) Importance of water globally and locally; (ii) Water problems in the world and in the local context; (iii) What causes water problems; (iv) How can the public solve water problems?; and (v) What can people do at home to contribute towards solving some of the water problems? An example an outline/ curriculum of a session workshop is as shown in Table 2.

\section{Table 2. Outline Curriculum of Water Awareness and Education Workshop}

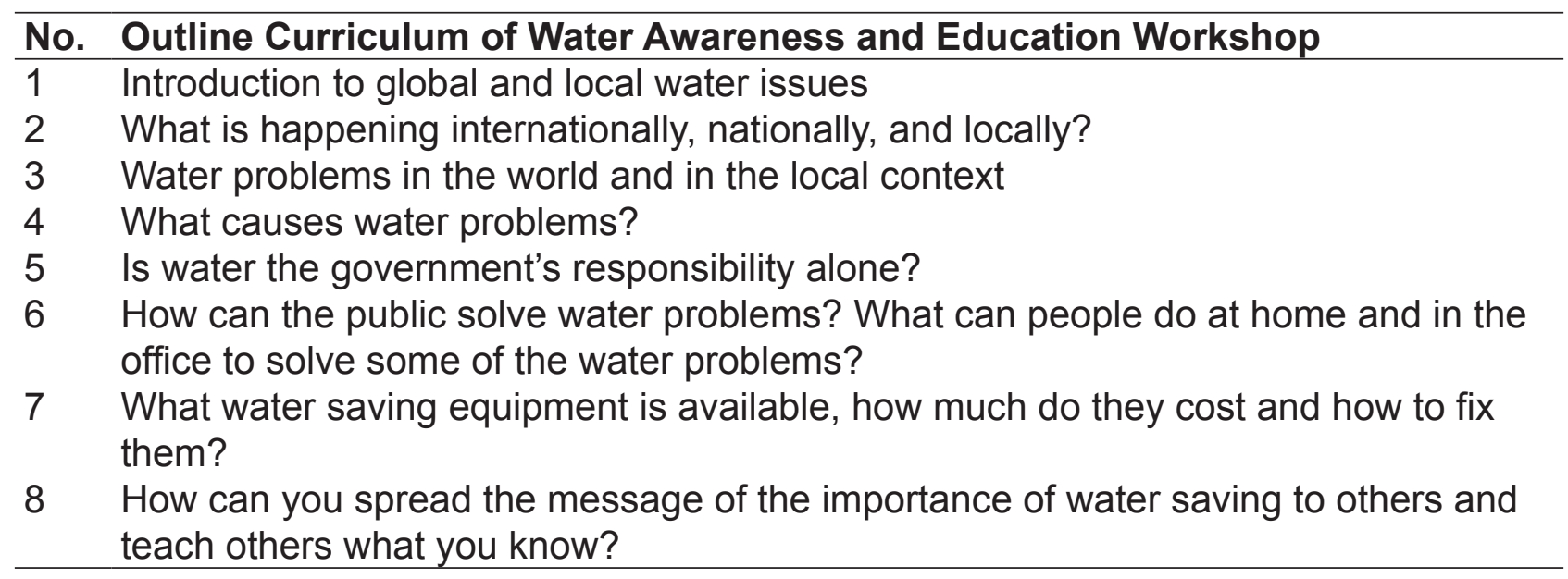

\section{Results and Discussion}

\section{The Rainfall Harvesting System}

The N-Park Rainfall Harvesting System showed that a large amount of rainwater can be harvested every month. This is because there is abundant rainfall every month, averaging between 200 to 500 $\mathrm{mm}$ per month. Hence, the lesson learnt is that Penang has high rainfall all year round and has great potentials for rainfall harvesting. Unfortunately, however, Penang is not capitalising on its rich potentials on rainwater at the moment. Installing a Rainfall Harvesting System in apartments is fairly easy as most rooftops have built-in gutters and drain-pipes trapping rain. The N-Park projected showed that the condominium has harvested more rainwater than it could use. To use more of the harvested rainwater, it needs to be diverted to the area whereby washing activities such as car washing and garbage bin washing take place. During every heavy rainstorm, the tanks would fill up quickly to the brim, each tank being of 10,000 litres capacity (Table 3 ). Table 4 is the updated recent harvested rainfall volumes in 2020 and 2021. Based on these two tables, it is clear that the apartment and its residents are not utilizing all its harvested rainwater. This is due to several reasons. Firstly, the cleaners and residents prefer to use the PBA piped water because of much better water pressures as they can complete their chores faster. Secondly, the apartment compound is small and there are not many lawns or plants to water (for gardening). Thirdly, rainfall tanks located in Blocks $B, C$ and $D$ car parks have no car-washing bays utilising rainwater. There are only two car-washing bays located on the ground floor of Block $A$. 
Fourthly, the rainwater is currently only used for flushing toilets in the badminton court toilets (one male and one female). Finally, the major landscaping plants are located on the southern side of all four blocks while the tanks are located on the northern side. It would take extensive piping connections to link the tanks to the southern side. After taking into consideration all these issues, the management committee subsequently put in more car washing bays in the vicinity of all 6 tanks and piped the water in some tanks to the gardens and lawns for gardening use. This has increased the usage of the harvested rainfall as can be seen in Table 4.

\section{Table 3. Accumulative Amount of Rainwater Harvested and Used from the 6 Rainwater Harvesting Tanks}

\begin{tabular}{|c|c|c|c|c|c|c|c|c|c|c|c|c|}
\hline \multirow[b]{2}{*}{ Date } & \multicolumn{2}{|c|}{ Tank 1} & \multicolumn{2}{|c|}{ Tank 2} & \multicolumn{2}{|c|}{ Tank 3} & \multicolumn{2}{|c|}{ Tank 4} & \multicolumn{2}{|c|}{ Tank 5} & \multicolumn{2}{|c|}{ Tank 6} \\
\hline & $\begin{array}{l}\text { Acc. } \\
\text { Cons. }\end{array}$ & $\begin{array}{l}\text { Vol. } \\
\text { Rem. }\end{array}$ & $\begin{array}{l}\text { Acc. } \\
\text { Cons. }\end{array}$ & $\begin{array}{l}\text { Vol. } \\
\text { Rem. }\end{array}$ & $\begin{array}{l}\text { Acc. } \\
\text { Cons. }\end{array}$ & $\begin{array}{l}\text { Vol. } \\
\text { Rem. }\end{array}$ & $\begin{array}{l}\text { Acc. } \\
\text { Cons. }\end{array}$ & $\begin{array}{l}\text { Vol. } \\
\text { Rem. }\end{array}$ & $\begin{array}{l}\text { Acc. } \\
\text { Cons. }\end{array}$ & $\begin{array}{l}\text { Vol. } \\
\text { Rem. }\end{array}$ & $\begin{array}{l}\text { Acc. } \\
\text { Cons. }\end{array}$ & $\begin{array}{l}\text { Vol. } \\
\text { Rem. }\end{array}$ \\
\hline May 2010 & 17 & 5,000 & 367 & 4,000 & 1,257 & 7,000 & 10 & 5,000 & 20 & 4,500 & 16 & 9,000 \\
\hline June 2010 & 24 & 5,000 & 1,211 & 4,100 & 3,669 & 2,900 & 12 & 5,000 & 21 & 5,000 & 19 & 9,500 \\
\hline July 2010 & 34 & 5,000 & 1,528 & 5,000 & 6,858 & 4,500 & 17 & 5,000 & 23 & 4,900 & 46 & 9,500 \\
\hline August 2010 & 51 & 5,000 & 2,099 & 5,000 & 12,030 & 5,000 & 22 & 5,000 & 27 & 5,000 & 120 & 9,500 \\
\hline September 2010 & 63 & 5,000 & 2,390 & 5,000 & 23,367 & 5,000 & 26 & 5,000 & 32 & 5,000 & 430 & 9,500 \\
\hline October 2010 & 90 & 5,000 & 2,720 & 5,000 & 36,102 & 3,000 & 31 & 5,000 & 35 & 5,000 & 845 & 9,500 \\
\hline November 2010 & 245 & 5,000 & 3,502 & 5,000 & 57,021 & 6,000 & 35 & 5,000 & 39 & 5,000 & 1,370 & 9,500 \\
\hline December 2010 & 2,307 & 5,000 & 4,301 & 5,000 & 73,103 & 8,500 & 37 & 5,000 & 43 & 5,000 & 2,104 & 9,500 \\
\hline January 2010 & 3,010 & 5,000 & 5,102 & 5,000 & 86,041 & 9,000 & 38 & 5,000 & 48 & 5,000 & 2,911 & 9,500 \\
\hline
\end{tabular}

Note: Acc.Cons = Accummulated Consumption; Vol.Rem. = Volume Remaining

Table 4. Rainfall Harvested and Usage in 2020 and 2021

\begin{tabular}{|c|c|c|c|c|c|c|c|c|c|c|c|c|}
\hline \multirow[b]{2}{*}{ Date } & \multicolumn{2}{|c|}{ Tank 1} & \multicolumn{2}{|c|}{ Tank 2} & \multicolumn{2}{|c|}{ Tank 3} & \multicolumn{2}{|c|}{ Tank 4} & \multicolumn{2}{|c|}{ Tank 5} & \multicolumn{2}{|c|}{ Tank 6} \\
\hline & $\begin{array}{l}\text { Acc. } \\
\text { Cons. }\end{array}$ & $\begin{array}{l}\text { Vol. } \\
\text { Rem. }\end{array}$ & $\begin{array}{l}\text { Acc. } \\
\text { Cons. }\end{array}$ & $\begin{array}{l}\text { Vol. } \\
\text { Rem. }\end{array}$ & $\begin{array}{l}\text { Acc. } \\
\text { Cons. }\end{array}$ & $\begin{array}{l}\text { Vol. } \\
\text { Rem. }\end{array}$ & $\begin{array}{l}\text { Acc. } \\
\text { Cons. }\end{array}$ & $\begin{array}{l}\text { Vol. } \\
\text { Rem. }\end{array}$ & $\begin{array}{l}\text { Acc. } \\
\text { Cons. }\end{array}$ & $\begin{array}{l}\text { Vol. } \\
\text { Rem. }\end{array}$ & $\begin{array}{l}\text { Acc. } \\
\text { Cons. }\end{array}$ & $\begin{array}{l}\text { Vol. } \\
\text { Rem. }\end{array}$ \\
\hline February 2020 & 2,350 & 5,200 & 3,110 & 4,200 & 3,340 & 6,200 & 3,353 & 5,550 & 1,245 & 6,206 & 1,120 & 5,200 \\
\hline April 2020 & 3,340 & 6,660 & 3,340 & 5,660 & 2,990 & 5,789 & 1,235 & 7,160 & 1,250 & 6,778 & 1,342 & 6,660 \\
\hline June 2020 & 1,290 & 7,000 & 2,390 & 6,550 & 3,100 & 6,678 & 2,255 & 5,698 & 2,100 & 7,060 & 1,550 & 7,000 \\
\hline July 2020 & 3,201 & 5,670 & 2,808 & 5,780 & 3,580 & 5,575 & 3,444 & 4,675 & 2,203 & 6,555 & 1,501 & 5,670 \\
\hline August 2020 & 3,336 & 4,500 & 3,115 & 4,100 & 3,535 & 4,445 & 3,456 & 4,566 & 1,290 & 7,300 & 1,809 & 4,500 \\
\hline October 2020 & 4,001 & 5,000 & 3,751 & 4,750 & 4,501 & 4,670 & 3,999 & 5,060 & 1,340 & 6,066 & 1,001 & 5,000 \\
\hline December 2020 & 2,369 & 5,000 & 4,345 & 4,400 & 2,679 & 4,805 & 2,789 & 5,600 & 2,000 & 6,005 & 1,359 & 5,000 \\
\hline February 2021 & 3,211 & 5,120 & 3,511 & 4,820 & 2,255 & 4,490 & 3,454 & 5,060 & 2,215 & 6,127 & 2,237 & 5,120 \\
\hline April 2021 & 3,349 & 620 & 3,549 & 5,600 & 1,249 & 5,578 & 3,446 & 5,000 & 2,370 & 5,200 & 2,990 & 6,200 \\
\hline
\end{tabular}

Note: Acc.Cons = Accummulated Consumption; Vol.Rem. = Volume Remaining 
Changing Water Saving Devices in Common Area Toilets

The total number of water-saving devices installed was 101 units. The types of Water Saving devices include: Dual flush cisterns; Automatic Push taps; and Push Urinals. The areas installed with such devices were the toilets on the ground floor near to the lifts in Block A, Block B, Block C and Block D. Water consumption data for the entire N-Park common area was recorded regularly after installation of devices. Before the launching of the rainfall harvesting system $\left(31^{\text {st }}\right.$ October 2009) and water saving devices installation (20 April 2010), it is clear that the average water consumption was very high, between $9000 \mathrm{~m}^{3}$ to $12000 \mathrm{~m}^{3}$ per two months. After both systems were installed, the water consumption showed a very significant decrease. This was reflected in the May, July and September 2010 water consumption figures which averaged between about 6000 $\mathrm{m}^{3}$ to $8000 \mathrm{~m}^{3}$. This is a significant decrease of about $33.3 \%$ in water consumption. In terms of monetary savings, $\mathrm{N}$-Park Condominium saved RM3,609.10, RM3,524.70 and RM1,249.20 for the billing months of May, July, and September respectively. This gave a total monetary savings of RM8,383.00 over a 6-month period (April to September 2010).

After April 2010, water consumption in subsequent months were significantly reduced. For example, May 2010 saw total water savings amounting to $3660 \mathrm{~m}^{3}$ or equivalent to a total percentage savings of $37 \%$. In July 2010 , total water savings was $3576 \mathrm{~m}^{3}$. This is equivalent to a savings of also $37 \%$. In September 2010, total water savings was $1174 \mathrm{~m}^{3}$, equivalent to a percentage savings of $12 \%$. On average, the percentage savings over the period was about $29 \%$ which is much higher (2.8 times) than the initial target of $10 \%$. Combined, over a one-year period from April 2010 to March 2011 , total water savings amounted to 16,818 $\mathrm{m}^{3}$ of water or the equivalent of monetary savings of RM16,782. More recently, between February 2020 and April 2021, the average water saved was $5852 \mathrm{~m}^{3}$ per month or averaging $48.77 \%$ per month, equivalent to about RM34,255 over the current period. This is a substantial amount of money saved. The water saving campaign also yielded encouraging results in terms of enhanced water awareness, increased water savings and better relationships between neighbours. In summary, the N-Park Negalitres project can be considered a great success and is arguably an exemplary Best Management Practice (BMP) in water conservation. As such, the project should be replicated in apartments all over the country. In fact, all large buildings with large water consumption have great potentials to adopt the N Park project, leading to greater water security in the state. Recent water consumption data in Table 5 indicates that after April 2010, the water consumption pattern continues to show a decreasing trend. 
Community Involvement in Urban Water Management: The N Park Resort Condominium Rainfall Harvesting and Water Saving Project in Penang, Malaysia

Table 5. The Total Water Consumption of the N-Park Common Areas Shows A Significant Decreasing Trend

\begin{tabular}{cccc}
\hline No. & Date & Water Usage $\left.\mathbf{( m}^{3}\right)$ & $\begin{array}{c}\text { Percentage Increase or } \\
\text { Decrease (\%) }\end{array}$ \\
\hline 1 & July 2009 & 12000 & $\begin{array}{c}\text { Base Month- } \\
2\end{array}$ \\
3 & Sep 2009 & 9000 & -25.00 \\
4 & Nov 2009 & 11000 & -8.33 \\
5 & Jan 2010 & 9000 & -25.00 \\
6 & Mar 2010 & 9800 & -18.33 \\
7 & May 2010 & 6000 & -50.00 \\
8 & Jul 2010 & 6100 & -49.17 \\
9 & Sep 2010 & 9100 & -24.17 \\
10 & Nov 2010 & 7000 & -41.67 \\
11 & Jan 2011 & 6300 & -47.50 \\
12 & Feb 2020 & 4513 & -62.39 \\
13 & Apr 2020 & 4870 & -59.42 \\
14 & Jun 2020 & 6344 & -47.13 \\
15 & Jul 2020 & 13066 & +8.88 \\
16 & Aug 2020 & 5225 & -56.46 \\
17 & Oct 2020 & 5225 & -56.46 \\
18 & Dec 2020 & 7699 & -35.84 \\
19 & Feb 2021 & 3994 & -66.72 \\
Average & Apr 2021 & 4397 & -63.36 \\
\hline
\end{tabular}

An interesting question was to find out whether the water savings were caused by water saving devices or by behavioral change in water consumers, or both. Subsequently, it was found that the water savings are mostly caused by water saving devices for various reasons: (i) Water consumers are reluctant to change their habits drastically as they have developed fixed ways in water usage; (ii) In the N-Park apartment common areas, there was substantial water savings and this could only be due to the replacement of water wasting devices with water saving devices; (iii) Water consumers are also reluctant to consciously change their routines because many find it troublesome; and (iv) In terms of residential water use, the 100 participating units registered a slight reduction in water use. This is again due to fixing water saving devices in their apartment units.
Enhancing Community Awareness in Water Conservation and Building Community Capacity in Sustainable Water Practices

The $\mathrm{N}$ Park project began with the objective of raising public awareness (of the residents) on the importance of water and water conservation. Interestingly, it gained much more than that. Before the project started, the N Park residents had low awareness about water conservation and were generally apathetic about water as it was cheap and readily available. However, as the project progressed, the residents became more and more involved and their awareness and education on water was enhanced. This was partly due to the monthly meetings and workshops on various issues of water management. The project also taught the residents how to save water, how 
to harvest rainfall, and how to use the water harvested. Towards the end of the project, most, if not all the participants were educated about water and had built up their capacities in water management, especially on water saving, water saving devices, and rainfall harvesting. Lastly, before the project started, most apartment residents hardly knew each other. They did not know their neighbours' names, where they work, their education, where they came from, etc. Hence, there was very little socializing between the residents. However, this changed as during the course of the project, those residents taking part had to interact with other residents, and in the process started to know each other. They learnt about the importance of water and its conservation, and learnt about their neighbours. Many participants became close friends after the project. Hence, the project succeeded in bringing residents together for a common cause. It improved residents' interactions, brought neighbours together, and instilled harmonious living amongst the residents of different age, gender, ethnic groups, religions and backgrounds. The residents were also more co-operative with the N Park management after they got to know each other in the project.

A total of 100 households of apartment units participated in the household water saving campaign. The starting month was April 2010. Water saving devices were provided by the project and 5 water saving devices were fitted in each participating apartment. Affordable water saving devices such as water regulators, thimbles, water saving showerheads and pressure control valves were fitted into the kitchen tap, showers and taps. The devices were given free and installed free of charge by a plumber. Results were very encouraging. Interestingly, water consumption during the pre-project period was substantially higher than the post-project period. After April 2010, water saving devices were installed and people were aware of water saving during monthly workshops. Water consumption for March 2010 (just before project start date) was about $3750 \mathrm{~m}^{3}$. From April 2010, a significant drop in consumption to $3490 \mathrm{~m}^{3}$ for the month of May 2010 followed by $3400 \mathrm{~m}^{3}$ in July 2010 . Overall, there was a slight decrease of $6.9 \%$ in May and $9.3 \%$ in July 2010 . This is a still a drop in water consumption.

Data from recent years were also added and they showed substantial savings. Despite the water savings achieved, changing people's water use behaviour was difficult. Many are used to their routines and are unwilling to change. For example, those who are used to having several showers a day are reluctant to reduce it to one or two showers a day. Those who wash their cars and bathrooms with a hose would not want to use a pail of water. One of the main reasons why people in Penang refuse to change their water-use behaviour is due to the state's extremely cheap water tariffs (compared to other countries and other Malaysian states) (Chan, 2020). Hence, Penangites also generally had an "apathetic" attitude towards water conservation. Penangites would save on energy, petrol, food and clothes, but would not save on water since it is so cheap. It costs only RM0.31 per cubic metre of water for domestic consumers.

Another huge challenge is to get participants committed as most are busy with their jobs and families, leaving little time to take part in the project. Many did not prioritise their time to this project as they failed to commit their time and effort to the project. Consequently, many participants even failed in their effort to save water. As a result of Penang's low awater tariffs (Chan, 2020), many participants were of the opinion that their water bills were already very low, with many paying only RM2.50 per month. As such, many felt it was not worth putting in the effort to save water as they could not save a lot of money. It was obvious that in order to convince people to save water, attractive incentives must be offered before people would get on board. In general, Penangites 
failed to understand that saving water is not about saving money but rather "saving water for the environment", "saving water for the futiure" or "saving water to avoid water crises". Penangites are generally very "moneyminded" and they viewed water saving, like many things else, as an investment, and as the rewards were not that attractive, they are not interested in taking part.

\section{Discussion on Community Engagement in Sustainable Urban Water Management}

This project is essentially about how local communities (in this case apartment residents) can take responsibility and get involved in urban water management. The time has arrived when not all urban water projects are solely the responsibility of the givernment or the private sector. Communities are educated and have the resources and responsibility to get actively engaged. Results of this project have indicated that communities can get involved, but their capacities need to be developed via training. For community urban water capacity development, this project used innovative contents whereby the training sessions were designed with specific water themes as follows: (i) Reasons for saving water; (ii) Domestic water saving tips; (iii) Issues, challenges and solutions related to water savings; (iv) Issues related to poor water quality; (v) Issues related to poor water pressure and its management; and (vi) Motivation to get involved in water saving. Based on the results of this study, it was clear that the water management capacities of many parties were improved. Firstly, the government via the DID managed to work closely with NGOs and local communities, something which they are not familiar with. This has enhanced their understanding and collaboration with these parties. Secondly, the same enhancement was seen in the private water company PBAPP Sdn Bhd, which began their collaboration with NGO (WWP), government (DID) and residents
(NPMC). The capacities of a local NGO WWP was also enhanced as WWP managed to run a big project and to work together in smart-partnerships with government, private sector and residents. This project showed that much more could be achieved when all these parties work together in collaboration rather than working in silos individually. By working together, all resources are pooled together and used effectively. The different expertise of various parties in the project complemented each other. Most importantly, the past "distorted" image of NGOs who were touted as "anti-government organisations" quickly evaporated when the parties started working together. No longer were NGOs seen as "anti-development", but they were transformed into "partners of government" and "pro-development".

This project also significantly empowered WWP as an NGO, especially working in urban water management. In the past, WWP mostly worked in the area of raising water awareness and providing water education to students and the public. However, this project highlighted its ability to work on a national project showcasing sustainable urban community water management. In this project, WWP partnered with local communities in collaborating with government agencies and private companies. In the past, WWP usually received funds or donations from donors, but in this project, WWP discovered that the government and private water companies can offer other resources such as expertise, human and equipment resources, transportation, links to other organisations, and other useful resources.

Interestingly also, this project discovered that the management corporation of apartments and condominiums such as $\mathrm{N}$ Park, are very interested in enhancing their water management, especially in the area of water savings. This is understandable as they stand to gain a lot in terms of water saved and money saved (from reduction in water bill). Many apartments are paying a 
huge monthly sum for their water bill. Hence, it makse sense for them to get engaged in water savings. As the N Park project became well known in the press, other apartments and condominiums have expressed their interest by contacting the $\mathrm{N}$ Park management to assist them in running similar water saving projects. Most interestingly, the Penang State Government was also keen on replicating the $\mathrm{N}$-Park project in other large apartments in Penang State. This is indeed a very good result of the $\mathrm{N}$ Park water saving project which is becoming sustainable by spreading its message and project elsewhere.

However, the project is not all success without problems. One of the biggest problems encountered was the initial difficulty of convincing the various parties to take part. Results from the project showed that the $\mathrm{N}$ Park residents needed to be convinced before thay agreed to take part. Several meetings and forums had to be conducted to inform the residents of the project to get them to buy in. Fortunately, with funding from the Federal Government via the Economic Planning Unit (EPU) and executed by DID, the project could be carried out successfully. It would be difficult without the government taking the lead role.

In summary, this project is considered a commendable success based on various results. Firstly, it brought together various diverse organisations from government to private sector, to NGO, resident association and local communities. These parties worked together very well, proving that such smartpartnerships are workable and should be the way forward in executing community-based urban water projects in the country. Secondly, the project also quashed the notion that private water companies are dead against water savings amongst water consumers as it may affet their profits. In fact, water companies like the PBAPP Sdn Bhd are very much in favour of encouraging water savings amongst its water consumers because this will reduce stress and pressures on the water supply system. Too much stress and pressures may lead to breakdown in water supply and imminent water crisis. This is what the PBAPP Sdn Bhd is trying to avoid at all costs. Thirdly, NGOs such as WWP have learnt to collaborate with government and private water companies. WWP has always worked with local communities and schools which it has lots of experience, but not with government and the private sector. This project has shown WWP the light and opened many doors to both government and private sector. WWP expects to get involved in many more projects with government and private sector in the future (Chan, 2019). Finally, residents as participants have increased their awareness and education on water, especially in their understanding of water issues (globally, nationally and locally) and the need to save water. They have also learnt the ways to save water and the ways to reduce their water demands. Consequently, improvement in their water saving capabilities are proven in the huge reduction in water consumption of the $\mathrm{N}$-Park condominium as well as in their own apartment unit's water consumption total.

\section{Conclusion}

As a developing country, Malaysia can no longer rely solely on government or the private sector to manage its water supply. Water security and sustainability cannot be achieved solely by one party. It must be achieved with all stakeholders each playing an active role. The N Park project has proven that engagement of all relevant stakeholders is the key towards successful urban water management. Results of this project also show that both technological change (e.g. replacing water wasting devices with water saving devices) and human behaviour change (e.g. from water wasting to water saving) are needed to ensure success in achieving water sustainability leading to achievement of Sustainable Development Goals (SDGs), especially SDG 6. 
Community urban water management is vital for water security enhancement. This project showed a substantial reduction in total water usage once the rainfall harvesting system and water saving devices were installed. The reduction was from 8 to $25 \%$ from September 2009 to March 2010, with the largest reduction of $50 \%$ between May and July 2011 , followed by $47.5 \%$ in January 2011. Similarly, the amount of monetary savings was also substantial at around RM1,397 per month or a yearly savings of RM16,782. In recent years, between February 2020 and April 2021, the average water saved was $5852 \mathrm{~m}^{3}$ per month (averaging $48.77 \%)$, equivalent to about RM34,255. It can be concluded that the N-Park Water Saving Project showed great successes in terms of consumption reduction in all three components of the project, with the rainwater harvesting component showing the greatest potential. Overall, all participants in the project were enlightened on the many advantages of Water Demand Management, Rainwater Harvesting, and Water Saving Devices.

The water saving campaign involving many forums and workshops brought the residents together, thereby fostering a greater sense of belonging in the condominium, closer relationships amongst residents, and getting the residents to know the N Park management committee. This project is touted as a Best Management Practice (BMP) in urban water management and has been actively publicized in the press and amongst apartment residents in Penang. The project shows a win-win approach for all stakeholders involved and proves that integrated water resources management is easily workable between Government, Private Sector, NGOs, and local communities. Finally, this project shows that government-private sector-NGOcommunities partnership is the way forward towards enhancing water security, as well as achieving SDGs for overall sustainable development in the country.

\section{Acknowledgements}

The authors thank the financial support of the FRGS Grant, Account Number 203. PHUMANITI.6711693, supported by the Ministry of Higher Education Malaysia for funding the presentation and publication of this paper, Drainage and Irrigation Department Malaysia for funding the rainfall harvesting project, PBAPP Sdn Bhd for providing water consumption data, Perbadanan Pengurusan N-Park for administrative support and Water Watch Penang for running the water saving campaign in the project.

\section{References}

Chan, N.W. 2002. "Rainfall Harvesting: Only One of Many Water Conservation Practices Towards the Evolution of a Water Saving Society". In Elias Ismail and S. Sundaraj (Editors) Proceedings of the Workshop on Rainfall Harvesting as a Tool for Sustainable Water Supply \& Storm-water Management. Kuala Lumpur: Construction Industry Development Board Malaysia, 11-26.

Chan, N. W. 2004. Managing Water Resources in the $21^{\text {st }}$ Century: Involving All Stakeholders Towards Sustainable Water Resources Management in Malaysia. Bangi: Environmental Management Programme, Centre for Graduate Studies, Universiti Kebangsaan Malaysia.

Chan, N. W. 2009. "The Environmental Humanities Initiative: Concept and Actualisation in Universiti Sains Malaysia as a Niche" Keynote paper presented at the workshop on The Establishment of the Research Cluster of "Environmental Humanities", Social Transformation Platform, Universiti Sains Malaysia, 2 May 2009.

Chan, N.W. 2010a. Changing Water Behaviour and Human Behaviour: Keys to Attaining Sustainable Water Resources Management. In Chan N.W. 
(Editor) Proceedings of the First National Seminar on Environmental Humanities. Penang: Social Transformation Platform, Universiti Sains Malaysia, 93.

Chan, N. W. 2010b. "Water Demand Management (Nega-Litres)

Demonstration Project at N-PARK Condominium BMP Project: A SmartPartnership Pilot Project on IWRM Involving Government-Private SectorNGO-Local Community". Keynote paper presented at National Seminar/ Workshop on Integrated Water Resources Management (IWRM) "Making IWRM Work at Local Level" - "Lessons Learnt", 25 October 2010, Tanjung Bungah Hotel, Penang.

Chan, N.W. 2012a. Managing Urban Rivers and Water Quality in Malaysia for Sustainable Water Resources. International Journal of Water Resources Development 28 (2), 343-354.

Chan, N.W. 2012b. Chapter 6 The N-Park Negalitres Project: A Pilot Water-Saving Initiative Using Green Technology and Changing Water Use Behaviour. In Ardakanian, R. and Dirk, J. (Editors) "Water and the Green Economy: Capacity Development Aspects". Bonn, UN-Water Decade Programme on Capacity Development (UNW-DPC): 7590.

Chan, N.W. 2017a. Achieving water resources security via Environmental Humanities: Examples from Malaysia. Plenary Speech III, Proceedings of 5th International Conference on Environmental Research \& Technology (ICERT 2017), 23-25 August 2017, Penang.

Chan, N. W. 2017b. Raising Awareness,

Education \& Commitment Amongst Penangites on the Importance of Water Conservation via Efficient Use of Water. Paper presented in the Penang Institute's Forum "Water Demand Management", $5^{\text {th }}$ April 2017, Penang Institute, Penang.
Chan, N.W. 2019. Holistic Urban Water Management Integrating Rainfall Harvesting, Water Conservation and Sustainable Drainage Systems in Universiti Sains Malaysia. Keynote Paper presented at the 5th International Conference on Advances in Environment Research (ICAER 2019), 13-15 August 2019, Nanyang Technological University Singapore, Hong Kong Chemical, Biological \& Environmental Engineering Society.

Chan, N.W. 2020. Averting Future Water Crises in Malaysia: Major Water Issues in Malaysia and Solutions to Address them. Paper presented at the National Public Forum "Averting Future Water Crisis: The Way Forward in Malaysia". Organised by Water Watch Penang-and School of Humanities, Universiti Sains Malaysia, 9 June 2020.

Geiger, R. 1954. "Klassifikation der Klimate nach W. Köppen" [Classification of climates after W. Köppen]. LandoltBörnstein - Zahlenwerte und Funktionen aus Physik, Chemie, Astronomie, Geophysik und Technik, alte Serie. Berlin: Springer 3, 603-607.

Hj Keizrul Abdullah. 2002. Integrated River Basin Management. In Chan, N. W. (Editor) Rivers: Towards Sustainable Development. Penerbit Universiti Sains Malaysia, Pulau Pinang, 3-14.

Quah, J.H. 2011. Keeping Penang watered. Penang Monthly, March, 2011.

Maidinsa, J. 2017. Water Demand Management: The Penang Story. Paper presented in the Penang Institute's Forum "Water Demand Management", $5^{\text {th }}$ April 2017, Penang Institute, Penang. Noresah Mohd Shariff, Sanjay Gairola and Anita Talib. 2010. Modelling Urban Land Use Change Using Geographically Weighted Regression and the Implications for Sustainable Environmental Planning. Proceedings of International Environmental 
Community Involvement in Urban Water Management: The N Park Resort Condominium Rainfall Harvesting and Water Saving Project in Penang, Malaysia

Modelling and Software Society (iEMSs) 2010 International Congress on Environmental Modelling and Software Modelling for Environment's Sake, Fifth Biennial Meeting, Ottawa, Canada David A. Swayne, Wanhong Yang, A. A. Voinov, A. Rizzoli, T. Filatova (Eds.) (http://www.iemss.org/iemss2010/index. php?n=Main.Proceedings Accessed 14 September 2017).

Phang Wai Ling, Chan Ngai Weng, Aminuddin Abd Ghani, Nor Azazi Zakaria, Jamaluddin Md Jahi \& Mazlin Mokhtar. 2013. Tahap Kesedaran dan Amalan Jimat Air di Kalangan Pengguna Domestik di Pulau Pinang. Dalam Jamaluddin Md. Jahi, Muhammad Rizal Razman, Kadir Arifin, Zuliskandar Ramli, Abdullah Sulaiman dan Emrizal (Penyunting) Prosiding SeminarSerantau Ke-2 Pengurusan Persekitaran di Alam Melayu, Pekanbaru, Provinsi Riau, 6-7 Mei 2013. Bangi: Institut Alam dan Tamadun Melayu (ATMa), Universitas Islam Riau dan Persatuan Pengurusan Persekitaran Malaysia, 126-135 (ISBN 978-983-2457-63-3).

Tortalajada, C. 2006. Singapore: An Exemplary Case for Urban Water Management. (http://hdr.undp.org/en/ reports/global/hdr2006/papers/Cecilia_ Tortajada_Singapore_casestudy.pdf 19/2/11).

www.waterwatchpenang.org (Accessed 17 September 2017). 